\title{
Monitoring of Heavy Metal Concentration in Groundwater of Mamundiyar Basin, India
}

\author{
Imran Ahmad Dar ${ }^{1}$, K. Sankar ${ }^{1}$, Dimitris Alexakis ${ }^{2}$ and Mithas Ahmad Dar ${ }^{1}$ \\ ${ }^{1}$ Department of Industries and Earth Sciences, Tamil University- Thanjavur \\ ${ }^{2}$ Centre for the Assessment of Natural Hazards and Proactive Planning, Laboratory of \\ Reclamation Works and Water Resources Management \\ National Technical University of Athens, Athens \\ ${ }^{2}$ Greece \\ ${ }^{1}$ India
}

\section{Introduction}

Heavy metals designate a group of elements that occur in natural system in minute concentration and when present in sufficient quantities and are toxic to living organisms. The behavior of trace metals in groundwater is complicated and is related to source of group water and the bio-geochemical process in elemental conditions.

It is often assumed that natural, uncontaminated waters from deep (bedrock) wells are clean and healthy (Banks et al., 1998b). This is usually true with regards to bacteriological composition. The inorganic chemical quality of these waters is, however, rarely adequately tested before the wells are put into production. Due to variations in the regional geology and water rock interactions, high concentrations of many chemical elements can occur in such waters. During the last 5-10 years several studies have shown that wells in areas with particular geological features yield water that does not meet established drinking water norms (e.g. Varsanyi et al., 1991; Bjorvatn et al., 1992, 1994; Edmunds and Trafford, 1993; Banks et al., 1995a,b, 1998a; Sæther et al., 1995; Reimann et al., 1996; Edmunds and Smedley, 1996; Smedley et al., 1996; Williams et al., 1996; Morland et al., 1997, 1998; Midtga ${ }^{\circ}$ rd et al., 1998; Misund et al., 1999; Frengstad et al., 2000) without any influence from anthropogenic contamination. These studies also document that quite a number of elements for which no drinking water guideline values (GL) or maximum acceptable concentration limits (MAC) have been established can occur at unpleasantly high levels in natural well waters (e.g. Be, $\mathrm{Th}, \mathrm{Tl}$ ). In Norway, $\mathrm{F}$ and radon ( $\mathrm{Rn})$ are the most problematic elements (see Frengstad et al., 2000) in terms of possible health effects. In Hungary, Bangladesh and India, arsenic represents one of the most drastic examples of unwanted natural chemical 'contamination' of groundwater. Several 100000 people in these regions suffer skin cancer due to high As concentrations in drinking water from drilled wells (Chatterjee et al., 1995; Das et al., 1995; Smith et al., 2000; Smedley and Kinniburgh, 2002).

It has been established that various trace elements have certain health on living organisms (WHO, 1984). But the extent to which these elements affect health of living organisms depends on the chemical characteristics and the concentration of the element in the water consumed. Furthermore, the time of exposure will also determine the level of the element on 
the organism. Some elements are biocumulative and therefore get increased with time in the body. The present paper reports analytical results for 6 chemical elements (trace elements) from 50 sampling stations of Mamundiyar basin, India.

\section{Geography and geology of the study area}

Mamundiyar basin, India lies in hard rock terrain. Groundwater is available only in weathered and fractured zones. In this area assured surface water supplies are nominal and most of the farmers depend on groundwater for drinking and irrigation purposes. Average annual rainfall is around $464 \mathrm{~mm}$ which is mostly lost as surface runoff and evaporation. Only one-fifth of it is recharging to groundwater. Therefore, groundwater development assumes great significance in improving the quality of life of the most deprived and vulnerable people of this basin by improving their access to safe drinking water.

The Mamundiyar basin extends over approximately $720 \mathrm{~km}^{2}$ and lies between $10^{\circ} 25^{`}$ and $10^{\circ} 40^{`} \mathrm{~N}$ latitudes and $78^{\circ} 10^{`}$ and $78^{\circ} 30^{`} \mathrm{E}$ longitudes in the southern part of Tamilnadu, India (Fig. 1). Mamundiyar River originates at an altitude of $315 \mathrm{~m}$ above Irungadu group of hills and joins Ariyavur River near Maravanur about $25 \mathrm{Km}$ south-west of Tiruchirapalli. The western, north-western and south-western parts are characterized by the presence of residual hills. The basin is generally hot and dry except during winter season. The mean maximum monthly temperature varies from $37^{\circ} \mathrm{C}$ in May to $29^{\circ} \mathrm{C}$ in December. While as mean minimum monthly temperature ranges from $27^{\circ} \mathrm{C}$ in June and $20^{\circ} \mathrm{C}$ in January. The area receives an average annual rainfall of about $464 \mathrm{~mm}$. The surface runoff goes to stream as instant flow. Rainfall is the direct recharge source and the irrigation return flow is the indirect source of groundwater in the Mamundiyar hydrographic basin. The study area depends mainly on the North-east monsoon rains which are brought by the troughs of low pressure established in the South Bay of Bengal.

Several digital image processing techniques, including standard color composites, intensityhue-saturation (IHS) transformation and decorrelation stretch (DS) were applied to map rock types. The statistical technique adopted by Sheffield (1985) was employed to select the most effective Three-band color composite image. The band combination 1, 4 and 5 is the best triplet and was used to create color composites with Landsat TM bands 5, 4 and 1 in red, green and blue, respectively. IHS transformation and DS were also applied to the selected band combination in order to enhance the difference between rock types. Better contrast was obtained due to color enhancement and this facilitated visual discrimination of various rock types. Eleven lithologic units were mapped and could be distinguished by distinct colors in the processed images. These are: Ultramafics, Hornblende biotite gneiss, Basic rocks, Charnockite, Pyroxene granulite, Pink magmatite, Quartzite, Pegmatite vein, Quartz vein, Granite, and Calc granulite and limestone. Fig. 2 is a map of the interpreted distribution of rock types Mamundiyar basin (Dar et. el, 2010).

\section{Sampling}

Most samples reported here were taken from drinking water wells in small villages and settlements scattered throughout the Mamundiyar basin, India. Factory new, unwashed 100$\mathrm{ml}$ high-density polyethylene (HDPE) bottles were used for sampling. Different brands of plastic bottles had previously been thoroughly checked for possible contamination (Reimann et al., 1999a). No risk of contamination from such bottles was found for the 


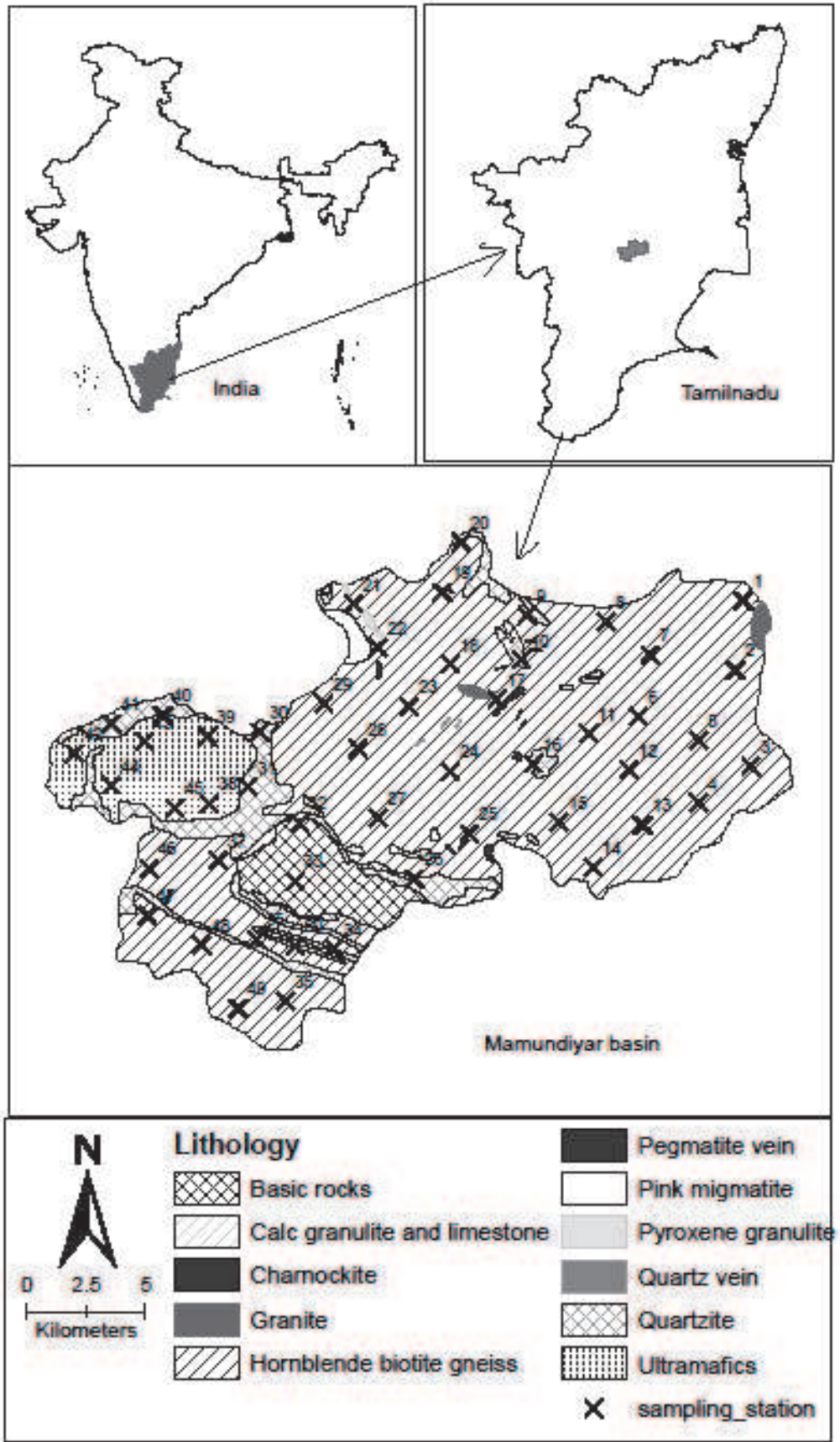

Fig. 1. 


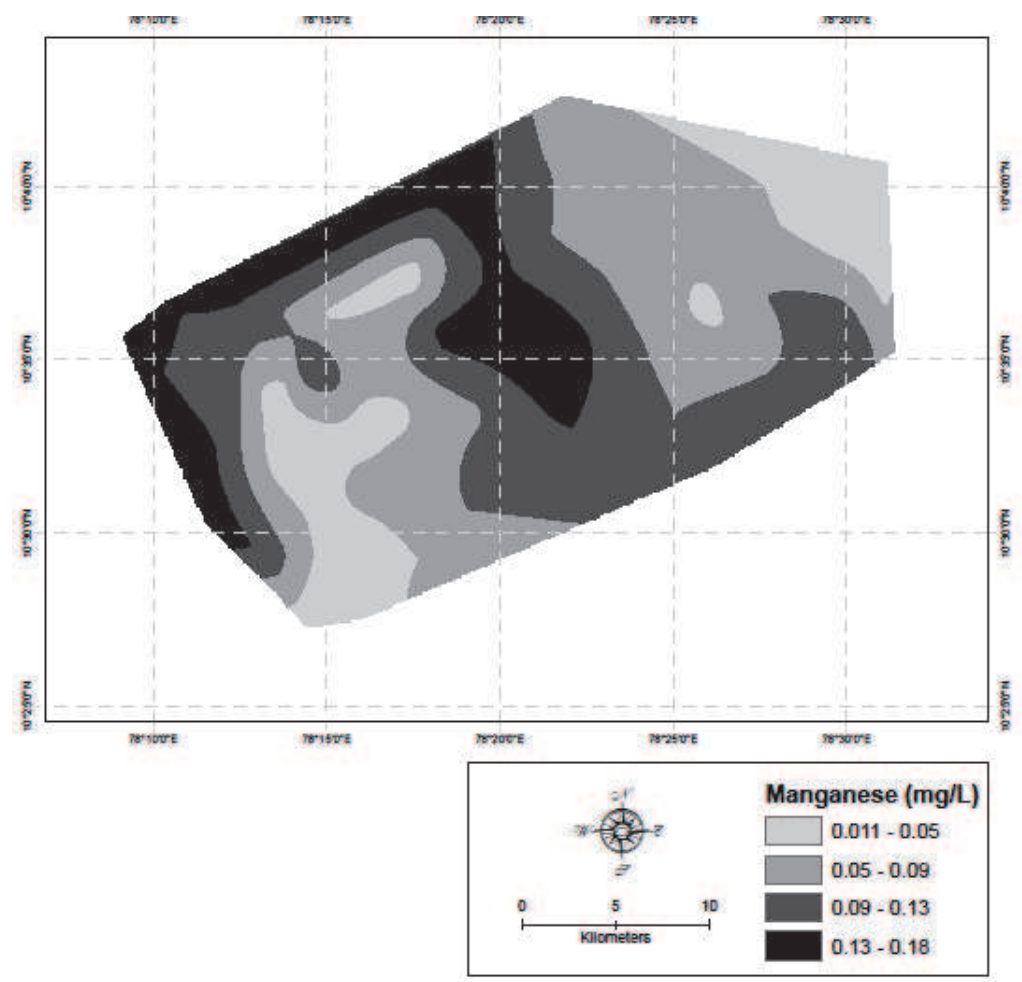

Fig. 2.

parameters reported here, as long as the bottles are thoroughly rinsed with water prior to sampling. In the field the bottles were rinsed three times with running water and then filled to the top.

Sampling took place directly at the tap or the wellhead. In order to collect fresh well water, the water was left running for at least $5 \mathrm{~min}$ or until temperature and conductivity remained stable. In most cases, each of these wells supplies more than 100 people with their daily drinking water. The water, therefore, never accumulates over longer periods in the well.

Two 100-ml bottles were collected at each site. The first sample, which was intended for anion analyses, was left unfiltered and unacidified. The unfiltered water of the second sample was acidified with $2 \mathrm{ml}$ of concentrated nitric acid (Merck, Ultrapure). This second sample was used later for cation analysis. The acid was tested for its trace element content using the same analytical procedure as for the water samples. In the field, the samples were stored in a cool box and in the evening transferred to a refrigerator, where they were stored until shipment to the laboratory.

\section{Analysis}

The trace elements analyzed included manganese $(\mathrm{Mn})$, iron $(\mathrm{Fe})$, chromium $(\mathrm{Cr})$, copper $(\mathrm{Cu})$, zinc $(\mathrm{Zn})$ and boron $(\mathrm{B})$. 


\section{Results and discussion}

The result of the analysis of 50 groundwater sampling stations is shown in tables 1 and 2 .

\begin{tabular}{|c|c|c|c|c|c|c|}
\hline Sample station & Zinc & Copper & Iron & Manganese & Chromium & Boron \\
\hline 1 & 0.01 & 0.02 & 0.03 & 0.011 & 0.001 & 0.38 \\
\hline 2 & 0.01 & 0.2 & 0.02 & 0.012 & 0.001 & 0.35 \\
\hline 3 & 0.04 & 0.03 & 0.03 & 0.07 & 0.002 & 0.31 \\
\hline 4 & 0.03 & 0.03 & 0.04 & 0.13 & 0.001 & 0.31 \\
\hline 5 & 0.04 & 0.03 & 0.03 & 0.12 & 0.001 & 0.4 \\
\hline 6 & 0.01 & 0.02 & 0.01 & 0.09 & 0.001 & 0.55 \\
\hline 7 & 0.07 & 0.03 & 0.02 & 0.05 & 0.002 & 0.56 \\
\hline 8 & 0.07 & 0.02 & 0.02 & 0.06 & 0.001 & 0.25 \\
\hline 9 & 0.006 & 0.03 & 0.04 & 0.08 & 0.001 & 0.38 \\
\hline 10 & 0.07 & 0.02 & 0.06 & 0.05 & 0.001 & 0.55 \\
\hline 11 & 0.03 & 0.03 & 0.06 & 0.04 & 0.001 & 0.31 \\
\hline 12 & 0.04 & 0.04 & 0.02 & 0.07 & 0.001 & 0.31 \\
\hline 13 & 0.02 & 0.03 & 0.2 & 0.13 & 0.002 & 0.4 \\
\hline 14 & 0.05 & 0.01 & 0.03 & 0.12 & 0.002 & 0.41 \\
\hline 15 & 0.002 & 0.02 & 0.03 & 0.09 & 0.002 & 0.32 \\
\hline 16 & 0.1 & 0.02 & 0.04 & 0.09 & 0.001 & 0.48 \\
\hline 17 & 0.1 & 0.02 & 0.04 & 0.09 & 0.001 & 0.55 \\
\hline 18 & 0.1 & 0.02 & 0.04 & 0.09 & 0.001 & 0.41 \\
\hline 19 & 0.1 & 0.02 & 0.04 & 0.09 & 0.001 & 0.31 \\
\hline 20 & 0.01 & 0.01 & 0.03 & 0.06 & 0.001 & 0.4 \\
\hline 21 & 0.07 & 0.02 & 0.04 & 0.18 & 0.001 & 0.12 \\
\hline 22 & 0.08 & 0.03 & 0.03 & 0.15 & 0.002 & 0.18 \\
\hline 23 & 0.002 & 0.03 & 0.03 & 0.14 & 0.001 & 0.38 \\
\hline 24 & 0.07 & 0.01 & 0.02 & 0.17 & 0.001 & 0.55 \\
\hline 25 & 0.08 & 0.01 & 0.03 & 0.13 & 0.001 & 0.31 \\
\hline 26 & 0.05 & 0.02 & 0.01 & 0.12 & 0.002 & 0.31 \\
\hline 27 & 0.002 & 0.03 & 0.03 & 0.08 & 0.001 & 0.4 \\
\hline 28 & 0.07 & 0.01 & 0.02 & 0.15 & 0.001 & 0.23 \\
\hline 29 & 0.05 & 0.03 & 0.03 & 0.02 & 0.002 & 0.31 \\
\hline 30 & 0.08 & 0.01 & 0.04 & 0.04 & 0.001 & 0.38 \\
\hline 31 & 0.07 & 0.02 & 0.06 & 0.13 & 0.001 & 0.55 \\
\hline 32 & 0.08 & 0.01 & 0.01 & 0.02 & 0.001 & 0.41 \\
\hline 33 & 0.07 & 0.03 & 0.01 & 0.07 & 0.002 & 0.31 \\
\hline 34 & 0.01 & 0.02 & 0.02 & 0.05 & 0.001 & 0.4 \\
\hline 35 & 0.07 & 0.02 & 0.02 & 0.04 & 0.002 & 0.32 \\
\hline 36 & 0.02 & 0.03 & 0.03 & 0.03 & 0.001 & 0.38 \\
\hline 37 & 0.08 & 0.01 & 0.12 & 0.02 & 0.002 & 0.42 \\
\hline 38 & 0.1 & 0.02 & 0.02 & 0.02 & 0.001 & 0.44 \\
\hline 39 & 0.1 & 0.01 & 0.03 & 0.1 & 0.001 & 0.47 \\
\hline 40 & 0.09 & 0.03 & 0.21 & 0.15 & 0.001 & 0.38 \\
\hline 41 & 0.07 & 0.01 & 0.02 & 0.14 & 0.002 & 0.55 \\
\hline 42 & 0.09 & 0.02 & 0.21 & 0.17 & 0.001 & 0.31 \\
\hline 43 & 0.1 & 0.01 & 0.03 & 0.12 & 0.001 & 0.31 \\
\hline 44 & 0.09 & 0.03 & 0.03 & 0.13 & 0.001 & 0.4 \\
\hline 45 & 0.07 & 0.03 & 0.04 & 0.1 & 0.002 & 0.38 \\
\hline 46 & 0.05 & 0.01 & 0.02 & 0.15 & 0.001 & 0.55 \\
\hline 47 & 0.02 & 0.02 & 0.02 & 0.17 & 0.001 & 0.31 \\
\hline 48 & 0.07 & 0.01 & 0.03 & 0.12 & 0.001 & 0.31 \\
\hline 49 & 0.08 & 0.03 & 0.03 & 0.02 & 0.001 & 0.4 \\
\hline 50 & 0.05 & 0.03 & 0.02 & 0.02 & 0.001 & 0.42 \\
\hline
\end{tabular}

Table 1. 


$\begin{array}{lcccccc}\text { Parameters } & \mathbf{z} & \mathbf{C u} & \mathbf{F e} & \mathbf{M n} & \mathbf{C r} & \mathbf{B} \\ \text { Minimum } & 0 & 0.01 & 0.01 & 0.01 & 0 & 0.12 \\ \text { Maximum } & 0.1 & 0.2 & 0.21 & 0.18 & 0 & 0.56 \\ \text { Range } & 0.1 & 0.19 & 0.2 & 0.17 & 0 & 0.44 \\ \text { Mean } & 0.06 & 0.03 & 0.04 & 0.09 & 0 & 0.38 \\ \text { Median } & 0.07 & 0.02 & 0.03 & 0.09 & 0 & 0.38 \\ \text { First quartile } & 0.03 & 0.01 & 0.02 & 0.05 & 0 & 0.31 \\ \text { Third quartile } & 0.08 & 0.03 & 0.04 & 0.13 & 0 & 0.42 \\ \text { Standard error } & 0 & 0 & 0.01 & 0.01 & 0 & 0.01 \\ \text { 95\% confidence interval } & 0.01 & 0.01 & 0.01 & 0.01 & 0 & 0.03 \\ \text { 99\% confidence interval } & 0.01 & 0.01 & 0.02 & 0.02 & 0 & 0.04 \\ \text { Variance } & 0 & 0 & 0 & 0 & 0 & 0.01 \\ \text { Average deviation } & 0.03 & 0.01 & 0.03 & 0.04 & 0 & 0.07 \\ \text { Standard deviation } & 0.03 & 0.03 & 0.05 & 0.05 & 0 & 0.1 \\ \text { Coefficient of variation } & 0.57 & 1.06 & 1.09 & 0.55 & 0.35 & 0.26 \\ \text { Skew } & -0.4 & 6.01 & 3.09 & 0 & 1.13 & 0.06 \\ \text { Kurtosis } & -1.2 & 40.1 & 9.06 & -1.2 & -0.8 & 0.2 \\ \text { Kolmogorov-Smirnov stat } & 0.22 & 0.39 & 0.38 & 0.13 & 0.46 & 0.15 \\ \text { Critical K-S stat, alpha=.10 } & 0.17 & 0.17 & 0.17 & 0.17 & 0.17 & 0.17 \\ \text { Critical K-S stat, alpha=.05 } & 0.19 & 0.19 & 0.19 & 0.19 & 0.19 & 0.19 \\ \text { Critical K-S stat, alpha=.01 } & 0.23 & 0.23 & 0.23 & 0.23 & 0.23 & 0.23\end{array}$

Table 2.

\section{Manganese}

The U.S. Public Health Service Drinking Water Standards of 1925, 1942, and 1946 included manganese with iron for a combined maximum level of $0.30 \mathrm{mg} / \mathrm{L}$, but in 1962 the regulations included, in addition, a maximum concentration of $0.05 \mathrm{mg} / \mathrm{L}$ for manganese. The USEPA adopted the $0.05 \mathrm{mg} / \mathrm{L}$ of the USPHS as recommendation, and issued a secondary standard in 1989. The WHO recommended $0.05 \mathrm{mg} / \mathrm{L}$ (maximum acceptable) and $0.50 \mathrm{mg} / \mathrm{L}$ as maximum allowable. The European Community (1980) used a guide value of $0.02 \mathrm{mg} / \mathrm{L}$ and a maximum of $0.05 \mathrm{mg} / \mathrm{L}$.

Figure 2 shows the spatial distribution of manganese through Natural Nearst Neighbor interpolation technique. It's quite obvious from the map that manganese tends to dominate the central part of the Mamundiyar basin, and its concentration diminishes radially outwards from the centre. The highest concentration of manganese found was 0.18 ; which means all the samples fall within the permissible limit set by WHO.

\section{Iron}

Since the standards for iron have been set for less than $0.3 \mathrm{mg} / \mathrm{L}$, acceptability of water sources was a condition for meeting this concentration. Groundwater exceeding this limit may need a treatment to meet the standard at the distribution system. Groundwater containing soluble iron may remain clear when pumped out, but exposure to air will cause precipitation of iron due to oxidation, with a consequence of rusty color. The presence of iron bacteria may clog well screens particularly when sulphate compounds in addition to iron may be subjected to chemical reduction. Solubility of iron is increased by a low $\mathrm{pH}(<5)$. 
High turbidity may help to keep acid- soluble iron in suspension. Iron in raw or potable water may be either ferrous or ferric or both and categorized as in solution, in colloidal state, in organic or inorganic compounds or in the form of coarse suspended or settled particles. The 1925 , 1942, 1946 and 1962 regulations of the U.S Public Health Service always reported the maximum concentration for iron as $0.30 \mathrm{mg} / \mathrm{L}$. the USEPA did not include iron in the National Drinking Water Quality Regulations, but maintained in the secondary Drinking Water Regulations of 1989 the limit of $0.3 \mathrm{mg} / \mathrm{L}$ based on aesthetic and taste consideration.

WHO (1963) also adopted a $0.3 \mathrm{mg} / \mathrm{L}$ as a maximum acceptable level and 1.0 as maximum allowable. The European Community adopted in 1980 a guide of $0.05 \mathrm{mg} / \mathrm{L}$ and a maximum of $0.20 \mathrm{mg} / \mathrm{L}$; WHO (1984 and 1993) recorded a guideline of $0.30 \mathrm{mg} / \mathrm{L}$. USEPA (1979 and 1991) confirmed the original ruling for iron as a contaminant to be included in the Secondary Drinking Water Standards with a level of $0.3 \mathrm{mg} / \mathrm{L}$ as the final rule.

Figure 3 shows the spatial distribution of iron using interpolation method in GIS environment. It's quite evident from the map that iron contaminations occur at few locations, mainly around the Kadavur (western) region of the Mamundiyar basin. In each patch, the concentration of iron was found to decrease/diminish radially outwards from centre. That means, at the point of rock (iron bearing) - water interaction, the concentration of Iron is maximum; and as the distance increases from the interface of rock (bearing iron element) and water, the concentration also gets decreased because of dilution factor. The values of iron were within the permissible limit of drinking water standards.

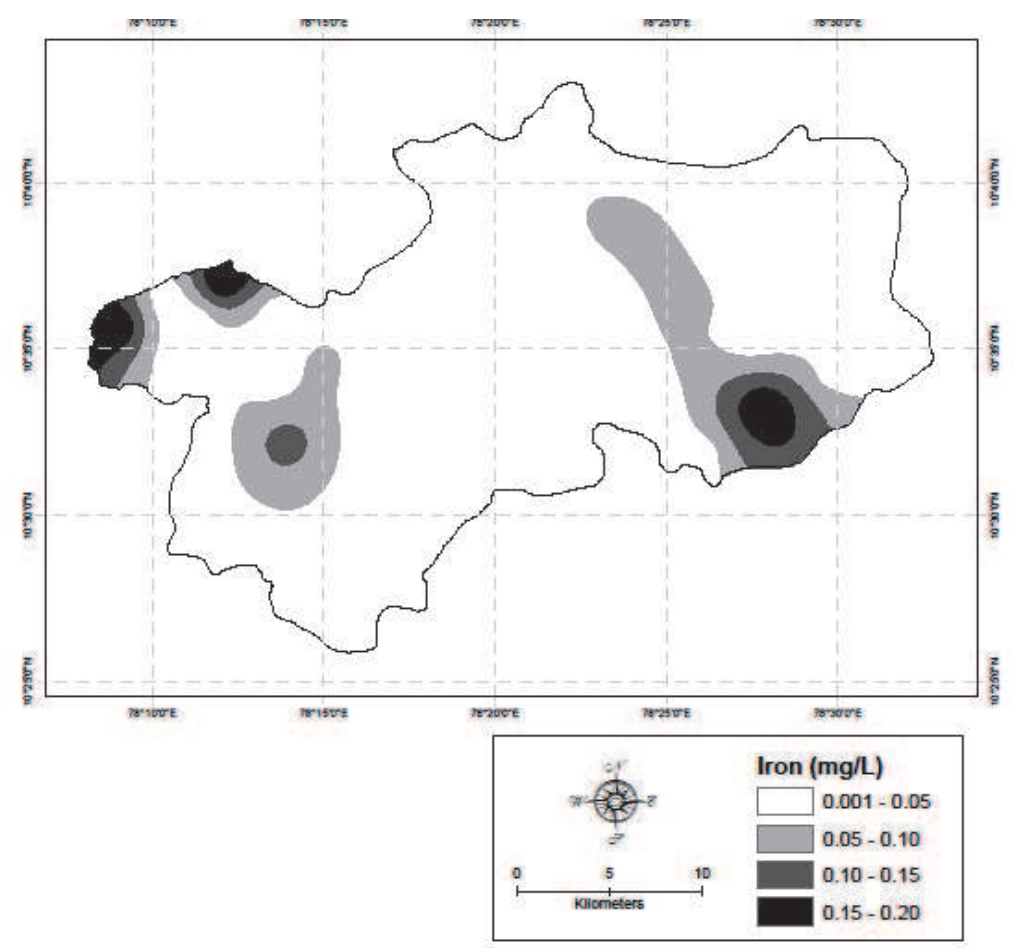

Fig. 3. 


\section{Chromium}

It's a naturally occurring metal in drinking water.

USPHS 1925

USPHS 1942

USPHS 1946

USPHS 1962

WHO guidelines

European Community

MCLG and MCL

(USEPA, 1989)

MCLG and MCL

(USEPA, 1991)
$=$ not stated

$=0 \mathrm{mg} / \mathrm{L}$ as hexavalent

$=0.05 \mathrm{mg} / \mathrm{L}$

$=0.05$ as hexavalent

$=0.05 \mathrm{mg} / \mathrm{L}$ (as $\mathrm{Cr}^{6+}$ and total chromium)

$=0.05 \mathrm{mg} / \mathrm{L}$ (as $\mathrm{Cr}^{6+}$ and total chromium)

$=0.1 \mathrm{mg} / \mathrm{L}$ (proposed)

$=0.1 \mathrm{mg} / \mathrm{L}$ (final; effective 7/30/1992)

The spatial distribution map of chromium is shown in figure 4; which is created using Nearest Neighbors interpolation technique. It's clear from the figure that the maximum concentration $(0.002 \mathrm{mg} / \mathrm{L})$ of chromium occurs in the southern region of Mamundiyar basin; and its concentration decreases towards the north-west, due to dilution. The concentration of chromium wherever recorded is well within the limits of drinking water standards prescribed by WHO.

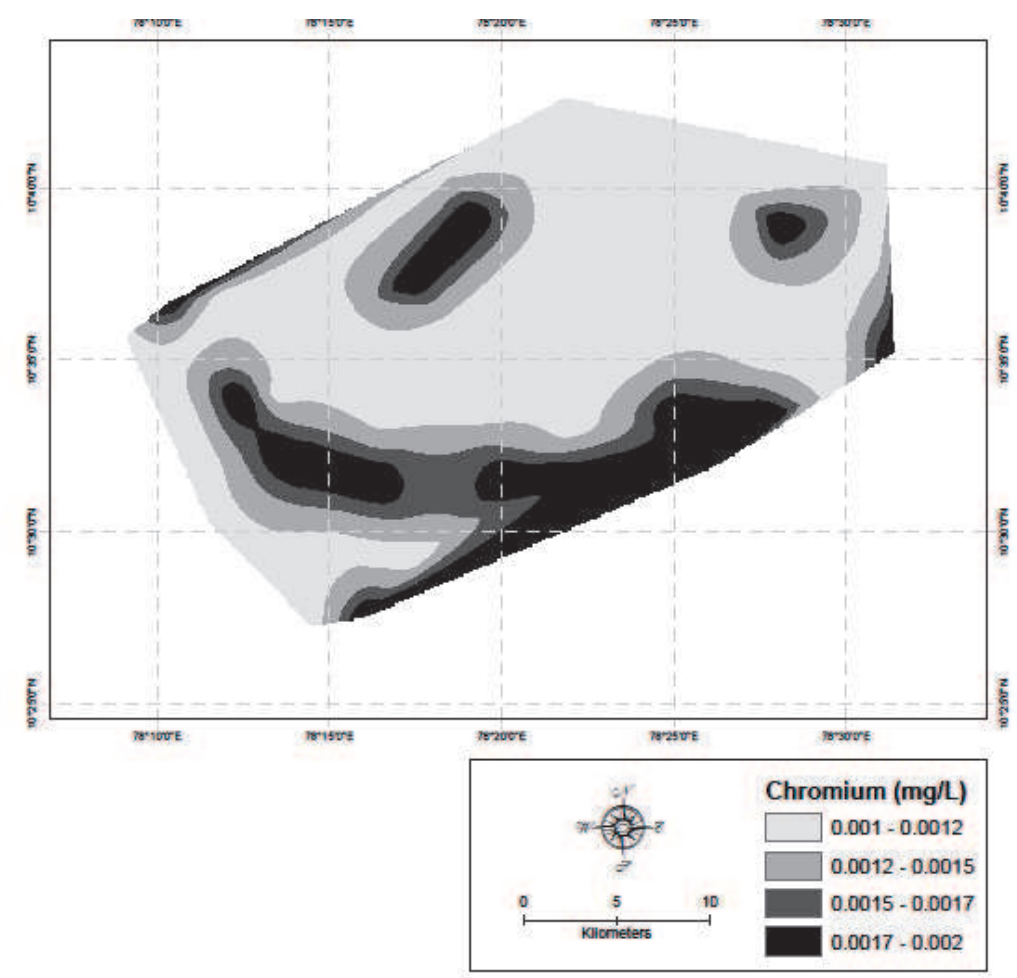

Fig. 4. 


\section{Copper}

USPHS 1925

USPHS 1942

$=0.2 \mathrm{mg} / \mathrm{L}$

USPHS 1962

$=3 \mathrm{mg} / \mathrm{L}$

$=1 \mathrm{mg} / \mathrm{L}$

WHO guidelines

$=1 \mathrm{mg} / \mathrm{L}(1.5 \mathrm{mg} / \mathrm{L}$ excessive $)$

European Community

$=0.1 \mathrm{mg} / \mathrm{L}$

MCLG and MCL

(USEPA, 1988)

MCLG and MCL

(USEPA, 1991)

$=1.3 \mathrm{mg} / \mathrm{L}$ (proposed)

$=1.3 \mathrm{mg} / \mathrm{L}$ at the consumer's tap (final revised regulations for lead and copper according to the New Lead and Copper Rule as requested by the Safe Drinking Water Act- Revision of 1986).

Copper can exist in aquatic environment in three forms namely soluble, colloidal and particulate. It is found in less quantity as an essential element for organisms. Excess of copper in human body is toxic and causes hypertension and produces pathological changes in brain tissues. Excessive ingestion of copper is responsible for specific disease of the bone (Krishnamurthy, C.R. and V. Pushpa. 1995). The spatial distribution map of copper (figure 5 ) is prepared using interpolation technique in GIS environment. It's quite obvious from the map that the maximum concentration of copper is present at eastern edge of Mamundiyar basin. In the present study, the values of copper are showed within the limit of drinking water standards.

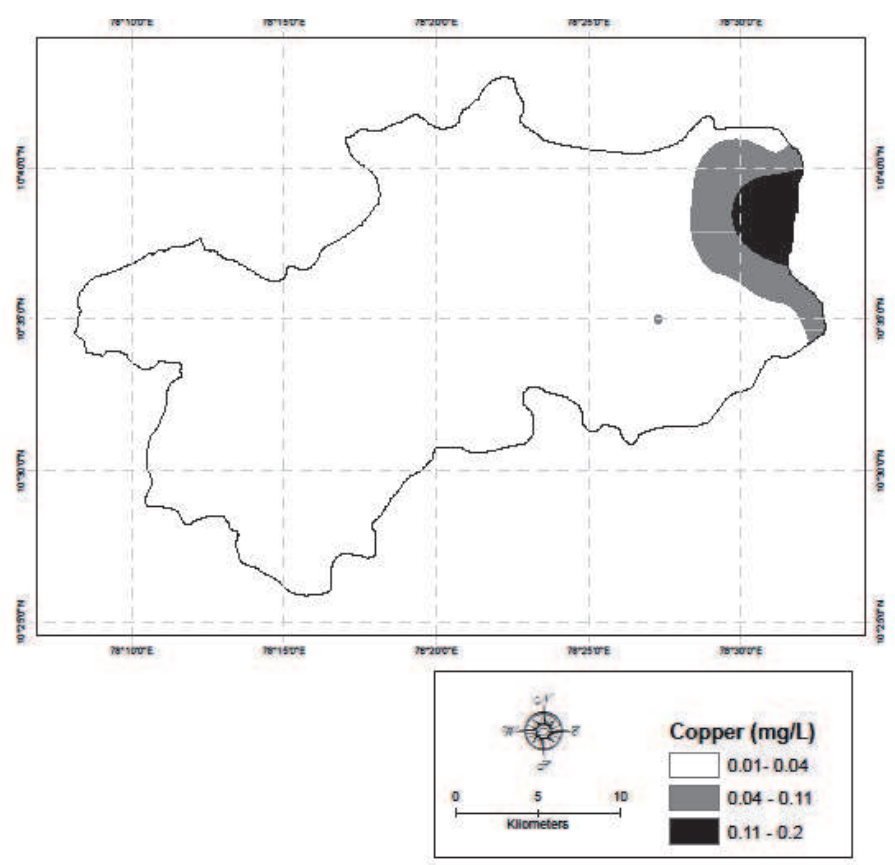

Fig. 5. 


\section{Zinc}

The USPHS recommended a maximum zinc concentration of $15.0 \mathrm{mg} / \mathrm{L}$ in 1942 and 1946 standards, and $5.0 \mathrm{mg} / \mathrm{L}$ in the 1962 standards.USEPA recommended $5 \mathrm{mg} / \mathrm{L}$ in 1980 and a SMCL of $5 \mathrm{mg} / \mathrm{L}$ in 1989. WHO (1971) recommended $5 \mathrm{mg} / \mathrm{L}$ with a maximum of $15 \mathrm{mg} / \mathrm{L}$. the European Community advised $0.1 \mathrm{mg} / \mathrm{L}$, with a maximum of $1.5 \mathrm{mg} / \mathrm{L}$. the WHO (1984) adopted a guideline of $5 \mathrm{mg} / \mathrm{L}$ based on the taste consideration. USEPA (1991) issued a final status for Zinc as a Secondary Drinking Water Standard (SDWS) of $5 \mathrm{mg} / \mathrm{L}$, confirming the final rule of $5 \mathrm{mg} / \mathrm{L}$ issued in 1980.

The spatial distribution map of zinc (figure 6) is prepared using interpolation technique in GIS environment. It's quite obvious from the map that the maximum concentration of zinc (0.5 MG/L) is present at the Kadavur (western) and central part of Mamundiyar basin. In the present study the values of zinc are showed within the limit of drinking water standard.

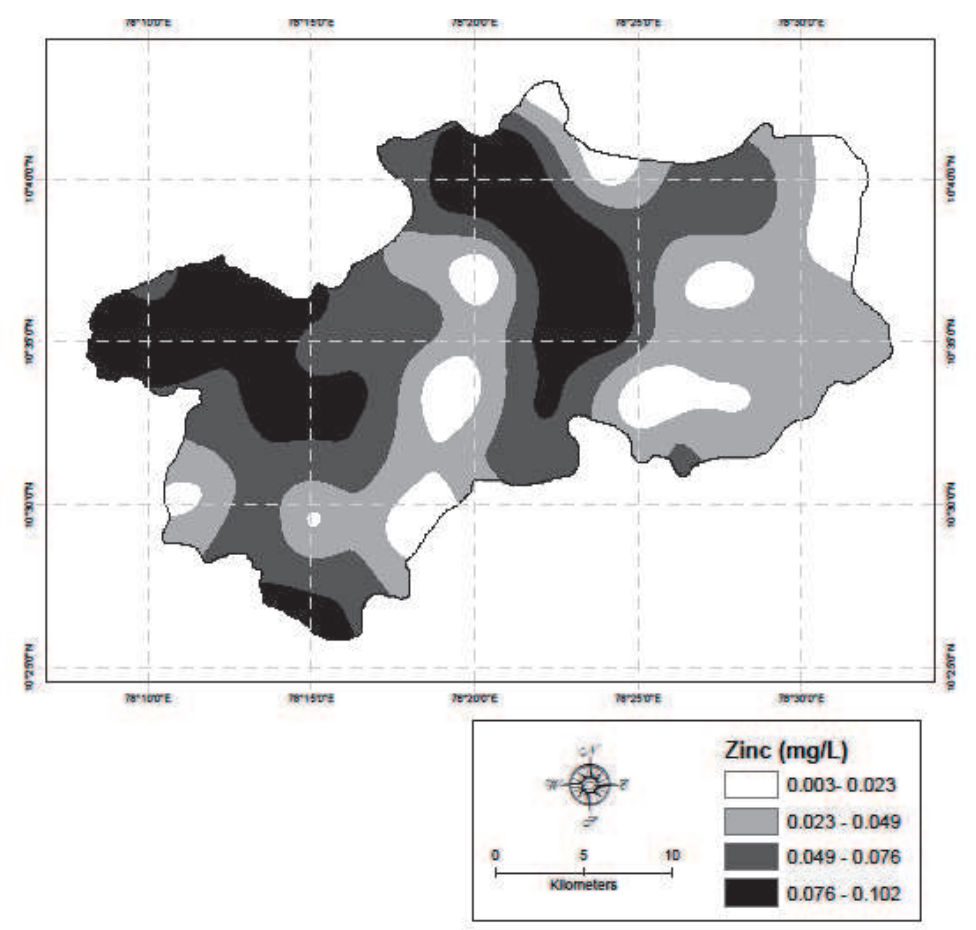

Fig. 6.

\section{Boron}

Spatial distribution map of boron (figure 7) depicts that maximum concentration of boron in patches at Central, Eastern and western part of Mamundiyar basin. Boron concentration varied between 0.11 to 0.56 , indicating that the samples fall within the permissible limit set by WHO. Overall, boron dominates the trace metal pool of the Mamundiyar basin as shown graphically in figure 8 . 


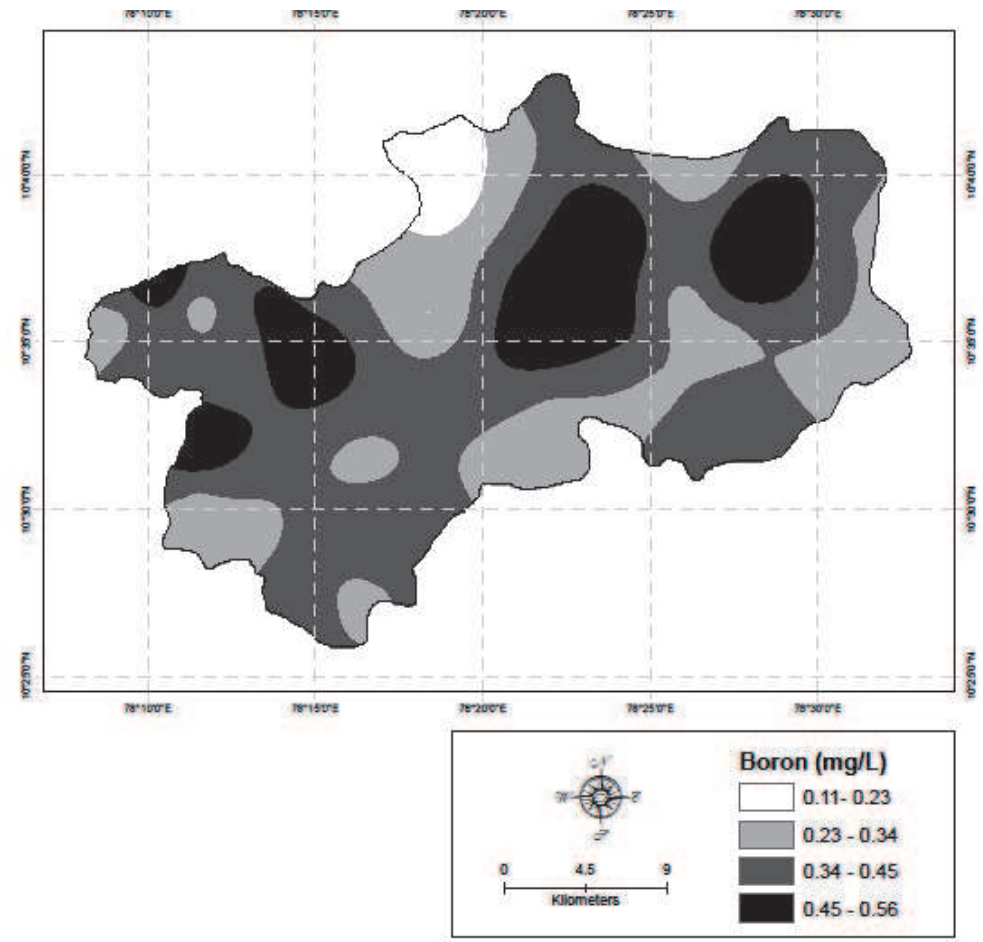

Fig. 7.

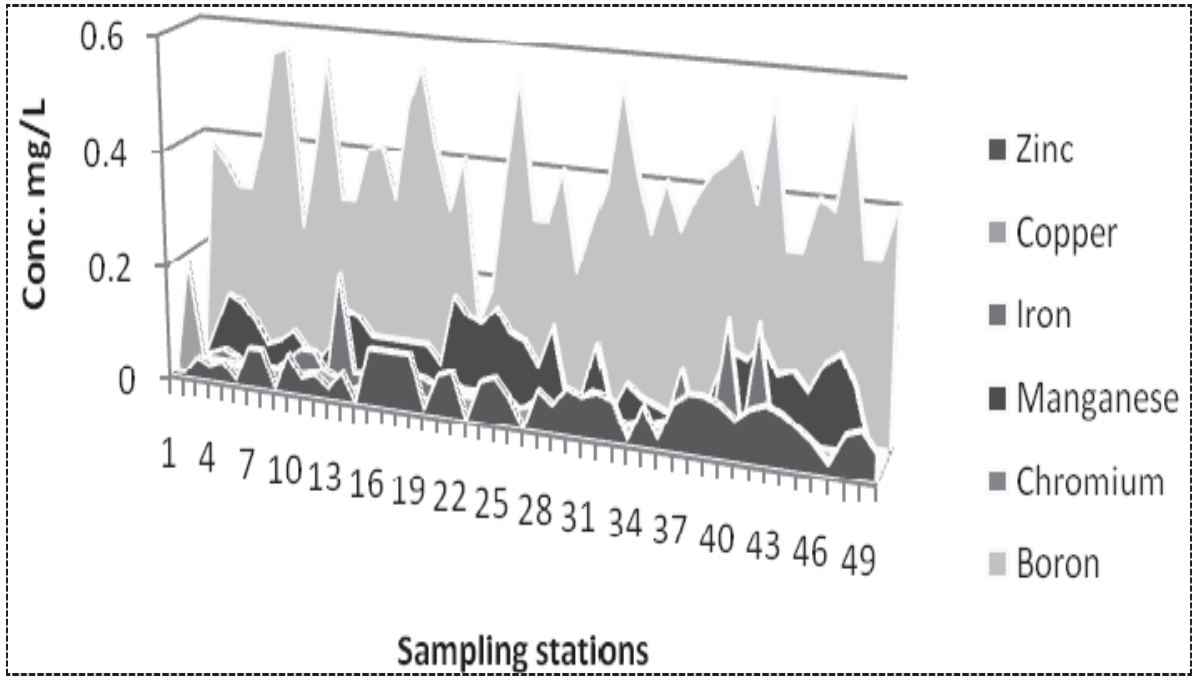

Fig. 8. 
The correlation between these parameters is shown in table 3 . The highest positive correlation (0.244) was found between iron and manganese, followed by iron and zinc (0.138). The lowest positive correlation (0.047) was found between iron and chromium. While as the highest negative correlation (- 0.293) was found between zinc and copper. Moreover, boron was found to show the negative correlation with all the parameters except zinc.

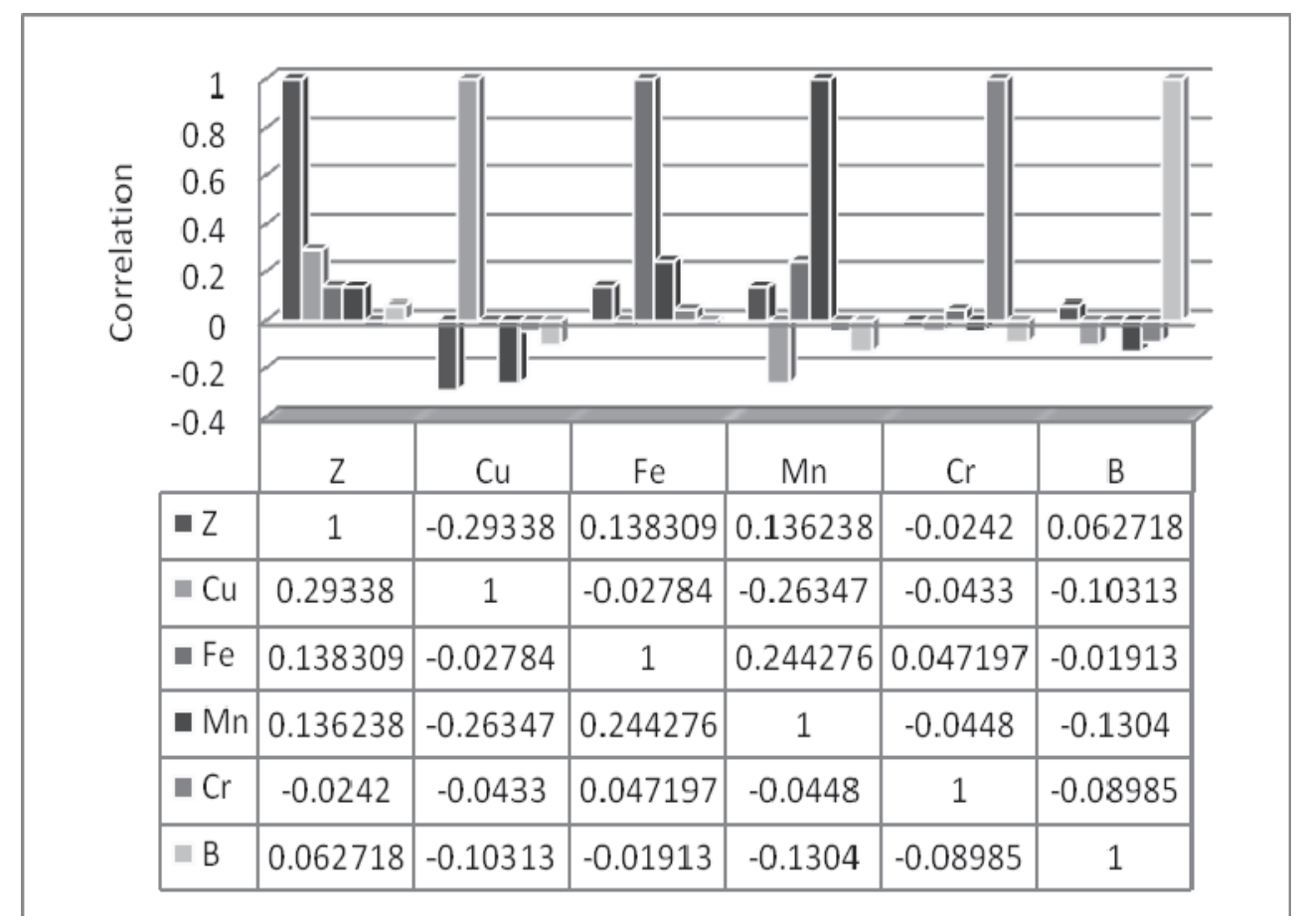

Table 3.

\section{Conclusion}

The concentrations of the investigated heavy metals $(\mathrm{Mn}, \mathrm{Fe}, \mathrm{Cr}, \mathrm{Cu}, \mathrm{Zn}$ and $\mathrm{B})$ in the drinking water samples from Mamundiyar basin, India were found below the guidelines for drinking waters given by the WHO (World Health Organization), EC (Europe Community), EPA (Environment Protection Agency). It was concluded that drinking waters in Mamundiyar contain low heavy metal levels.

\section{References}

Banks D, Frengstad B, Midtga ${ }^{\circ}$ rd AK, Krog JR, Strand T. The chemistry of Norwegian groundwaters: I. The distribution of radon, major and minor elements in 1604 crystalline bedrock groundwaters. Sci Total Environ 1998;222:71 -91. 
Banks D, Midtga ${ }^{\circ}$ rd AK, Morland G, Reimann C, Strand T, Bjorvatn K, Siewers U. Is pure groundwater safe to drink? Natural 'contamination' of groundwater in Norway. Geol Today 1998;14(3):104 -113.

Banks D, Reimann C, Røyset O, Skarphagen H. Natural concentrations of major and trace elements in some Norwegian bedrock groundwaters. Appl Geochem 1995;10:1 - 16.

Banks D, Røyset O, Strand T, Skarphagen H. Radioelement (U,Th, Rn) concentrations in Norwegian bedrock groundwaters. Environ Geol 1995;25:165 -180.

Bjorvatn K, Ba ${ }^{\circ}$ rdsen $\mathrm{A}^{\circ}$, Thorkildsen $\mathrm{AH}$, Sand K. Fluorid I norsk grunnvann - en ukjent helsefaktor wFluoride in Norwegian drinking water-an unknown health factorx. Vann 1994;2:120 -128. in Norwegian.

Bjorvatn K, Thorkildsen AH, Holteberg S. Sesongmessige variasjoner i fluoridinholdet i sør og vestnorsk grunnvann [Seasonal variations of the fluoride content in south and west Norwegian groundwaters]. Den norske tannlegeforenings tidende 1992;102:128 -133. in Norwegian

Chatterjee A, Das D, Mandal BK, Chowdhurry TR, Samanta G, Chakraborti D. Arsenic in groundwater in six districts of West Bengal, India: the biggest arsenic calamity in the world. Part 1: arsenic species in drinking water and urine of affected people. Analyst 1995;120:643 -650.

Dar IA, Sankar K, Dar MA, Remote sensing technology and geographic information system modeling: An integrated approach towards the mapping of groundwater potential zones in Hardrock terrain, Mamundiyar basin. Journal of Hydrology (2010) 394: 85-295

Das D, Chatterjee A, Mandal BK, Samanta G, Chakraborti D. Arsenic in groundwater in six districts of West Bengal, India: the biggest arsenic calamity in the world. Part 2: arsenic concentration in drinking water, hair, nails, urine, skin scale and liver tissue (biopsy) of the affected people. Analyst 1995;120:917 -924.

Edmunds WM, Smedley PL. Groundwater geochemistry and health: an overview. In: Appleton JD, Fuge R, mccall GJH, editors. Environmental geochemistry and health. Geological Society Special Publication 113 1996. P. 91 -105.

Edmunds WM, Trafford JM. Beryllium in river baseflow, shallow groundwaters and major aquifers of the UK. Appl Geochem 1993;2(Suppl):223 -233.

European Union. 80y778yeec Council Directive of 15 July 1980 relating to the quality of water intended for human consumption. Official Journal of the European Community 1980. P. L229y11 -L229y29.

European Union. Council Directive 98y83yec of 3 November 1998 on the quality of water intended for human consumption. Official Journal of the European Community 1998. P. L330y32 -L330y54.

Frengstad B, Midtga ${ }^{\circ}$ rd AK, Banks D, Krog JR, Siewers U. The chemistry of Norwegian groundwaters. III. The distribution of trace elements in 476 crystalline bedrock groundwaters, as analysed by ICP-MS techniques. Sci Total Environ 2000;246: $21-40$.

Krishnamurthy, C.R. and V. Pushpa. 1995. Toxic metals in the Indian Environment. Tata McGraw Hill Publishing Co. Ltd., New Delhi. pp 280.

Midtga ${ }^{\circ}$ rd AK, Frengstad B, Banks D, Krog JR, Strand T, Siewers U. Drinking water from crystalline bedrock aquifers - not just H2O. Min Soc Bull 1998;121:9 -16. 
Misund A, Frengstad B, Siewers U, Reimann C. Natural variation of 66 elements in European mineral waters. Sci Total Environ 1999;243y244:21 -41.

Morland G, Reimann C, Strand T, Skarphagen H, Banks D, Bjorvatn K, Hall GEM, Siewers $\mathrm{U}$. The hydrogeochemistry of Norwegian bedrock groundwater-selected parameters (ph, Fy, Rn, U, Th, B, Na, Ca) in samples from Vestfold and Hordaland, Norway. NGU Bull 1997;432:103 -117.

Morland G, Strand T, Furuhaug L, Skarphagen H, Banks D. Radon concentrations in groundwater from Quaternary sedimentary aquifers in relation to underlying bedrock geology. Ground Water 1998;36:143 -146.

Reimann C, Hall GEM, Siewers U, Bjorvatn K, Morland G, Skarphagen H, Strand T. Radon, fluoride and 62 elements as determined by ICP-MS in 145 Norwegian hardrock groundwaters. Sci Total Environ 1996;192:1 -19

Reimann C, Siewers U, Skarphagen H, Banks D. Does bottle type and acid washing influence trace element analyses by ICP-MS on water samples? A test covering 62 elements and four bottle types: high-density polyethene (HDPE), polypropene (PP), fluorinated ethene propene copolymer (FEP) and perfluoroalkoxy polymer (PFA). Sci Total Environ 1999;239:111 -130.

Sæther O, Reimann C, Hilmo BO, Taushani E. Chemical composition of hard- and softrock groundwaters from central Norway with special consideration of fluoride and Norwegian drinking water limits. Environ Geol 1995;26(3):147 - 156.

Smedley PL, Edmunds WM, Pelig-Ba KB. Mobility of arsenic in groundwater in the Obuasi gold-mining area of Ghana: some implications for human health. In: Appleton JD, fuger, mccall GJH, editors. Environmental geochemistry and health. Geological Society Special Publication 113 1996. P. 163 -181.

Smedley PL, Kinniburgh DG. A review of the source, behavior and distribution of arsenic in natural waters. Appl Geochem 2002;17(5):517 -568.

Smith AH, Lingas EO, Rahman M. Contamination of drinking water by arsenic in Bangladesh: a public health emergency. Bull WHO 2000;78(9):1093 -1101.

USEPA, 1989. National Primary and Secondary Drinking Water Regulations, Proposed Rule, Fed. Reg. (Vol. 54, No. 97).

USEPA, 1991. Safe Drinking Water Act, 1991 Amendments, EPA 570/9-86-002. Washington, D.C.

USPHS, Drinking water standards, Unitede States Public Health Services, 1987, Washington DC.

Varsanyi I, Fodre Z, Bartha A. Arsenic in drinking water and mortality in the Southern Great Plain, Hungary. Environ Geochem Health 1991;13:14 -22

WHO. Guidelines for drinking water quality. Geneva: World Health Organisation, 1993.

WHO. Guidelines for drinking-water quality. Addendum to vol. 1. Recommendations, 2nd ed. Geneva: World Health Organisation, 1998. P. 10 -11.

WHO: 1984, Guidelines for Drinking Water Quality, Geneva.

Williams M, Fordyce F, Paijiprapapon A, Charoenchaisri P. Arsenic contamination in surface drainage and groundwater in part of the Southeast Asian tin belt, Nakhon Si Thamarat Province, southern Thailand. Environ Geol 1996;27:16 -33. 


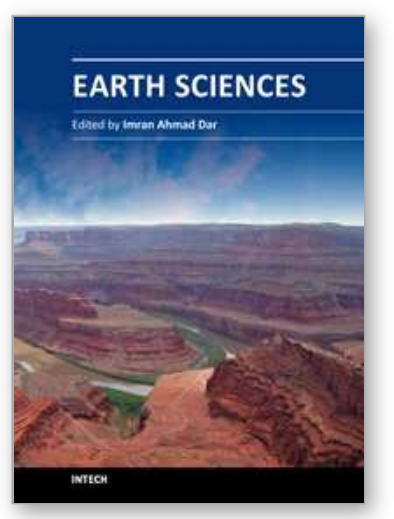

\author{
Earth Sciences \\ Edited by Dr. Imran Ahmad Dar
}

ISBN 978-953-307-861-8

Hard cover, 648 pages

Publisher InTech

Published online 03, February, 2012

Published in print edition February, 2012

The studies of Earth's history and of the physical and chemical properties of the substances that make up our planet, are of great significance to our understanding both of its past and its future. The geological and other environmental processes on Earth and the composition of the planet are of vital importance in locating and harnessing its resources. This book is primarily written for research scholars, geologists, civil engineers, mining engineers, and environmentalists. Hopefully the text will be used by students, and it will continue to be of value to them throughout their subsequent professional and research careers. This does not mean to infer that the book was written solely or mainly with the student in mind. Indeed from the point of view of the researcher in Earth and Environmental Science it could be argued that this text contains more detail than he will require in his initial studies or research.

\title{
How to reference
}

In order to correctly reference this scholarly work, feel free to copy and paste the following:

Imran Ahmad Dar, K. Sankar, Dimitris Alexakis and Mithas Ahmad Dar (2012). Monitoring of Heavy Metal Concentration in Groundwater of Mamundiyar Basin, India, Earth Sciences, Dr. Imran Ahmad Dar (Ed.), ISBN: 978-953-307-861-8, InTech, Available from: http://www.intechopen.com/books/earth-sciences/monitoring-ofheavy-metal-concentration-in-groundwater-of-mamundiyar-basin-india

\section{INTECH}

open science | open minds

\author{
InTech Europe \\ University Campus STeP Ri \\ Slavka Krautzeka 83/A \\ 51000 Rijeka, Croatia \\ Phone: +385 (51) 770447 \\ Fax: +385 (51) 686166 \\ www.intechopen.com
}

\author{
InTech China \\ Unit 405, Office Block, Hotel Equatorial Shanghai \\ No.65, Yan An Road (West), Shanghai, 200040, China \\ 中国上海市延安西路65号上海国际贵都大饭店办公楼405单元 \\ Phone: +86-21-62489820 \\ Fax: $+86-21-62489821$
}


(C) 2012 The Author(s). Licensee IntechOpen. This is an open access article distributed under the terms of the Creative Commons Attribution 3.0 License, which permits unrestricted use, distribution, and reproduction in any medium, provided the original work is properly cited. 